\begin{tabular}{|c|c|c|}
\hline 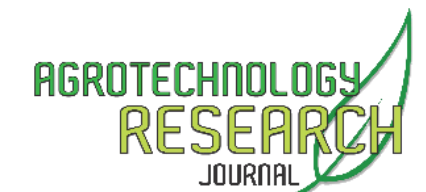 & $\begin{array}{c}\text { Agrotech Res J, June } 2019,3(1): \text { 8-12 } \\
\text { AGROTECHNOLOGY RESEARCH } \\
\text { JOURNAL }\end{array}$ & $\begin{array}{l}\text { ISSN 2655-7924 (Print) } \\
\text { ISSN 2614-7416 (Online) } \\
\text { https://jurnal.uns.ac.id/arj } \\
\text { doi:10.20961/agrotechresj.v3i1.25254 }\end{array}$ \\
\hline
\end{tabular}

\title{
Intensitas Serangan Hama pada Beberapa Jenis Terung dan Pengaruhnya terhadap Hasil
}

\author{
Eko Apriliyanto ${ }^{1 *}$, Bondan Hary Setiawan ${ }^{2}$ \\ 1,2 Department of Agriculture, Politeknik Banjarnegara, Banjarnegara, Indonesia
}

${ }^{*}$ Corresponding Author:

E-mail: okeapriliyanto@gmail.com

Received 12 November 2018; Accepted 8 February 2019; Published 30 June 2019

\begin{abstract}
Eggplant pest attack, does not only decrease quantity of the yields, but also the quality. Because of this, it needs effort to use resistant eggplant againt the pests. The purpose of this research was to evaluate the intensity of pest attack on several types of eggplant and their effect on the yield. The design used in the study was a completely randomized block design (RCBD). The research was consisted of 4 treatments with 3 replications. The treatments were 4 types of eggplant that were purple, white eggplant, green eggplant, and green streak white. Data were analyzedby $F$ Test, if it was significantly different, by then it was continued with DMRT (Duncan's Multiple Range Test) at the level of $5 \%$. Pest attack intensity of grasshopper (Orthroptera: Acrididae), caterpillars (Lepidoptera: Pyralidae), ladybird Epilachna sp. (Coleoptera: Coccinellidae), leafhopper Amrasca sp. (Hemiptera: Cicadellidae), and Aphis sp. (Hemiptera: Aphididae) on the eggplant types showed there was no significantly difference. The intensity of pest attacks which were not significantly different in all types of eggplant along with the results of analysis of plant height and number of fruits which also showed there was no significantly difference in all type eggplants.
\end{abstract}

Keywords: Grasshopper; Caterpillar; Ladybird; Leafhopper; Aphids

(c) 2019 Agrotechnology Research Journal

Cite This As: Apriliyanto E, Setiawan BH. 2019. Intensitas Serangan Hama pada Beberapa Jenis Terung dan Pengaruhnya terhadap Hasil. Agrotech Res J 3(1): 8-12. https://doi.org/10.20961/agrotechresj.v3i1.25254

\section{PENDAHULUAN}

Terung (Solanum melongena L.) merupakan komoditi hortikultura yang memiliki nilai ekonomi tinggi. Buah terug sering dijadikan sebagai sayur dalam melengkapi lauk pada menu sehari-hari. Buah terung juga dapat dijadikan menjadi aneka makanan ringan atau camilan. Kadiret al. (2015) menyatakan bahwa anyaknya bentuk makanan ringan yang dikomsumsi oleh masyarakat saat ini merupakan salah satu bentuk kegemaran oleh para konsumen dalam mengkomsumsi makanan ringan. Aer et al. (2013) menyatakan bahwa pada umumnya masyarakat telah mengenal, mengonsumsi terung ungu dan menggunakannya secara empiris dalam pengobatan diabetes.

Rendahnya hasil terung dapat disebabkan oleh berbagai faktor antara lain; tanah yang kurang subur, tindakan budidaya yang kurang baik, kondisi iklim yang kurang mendukung serta kurangnya keahlian petani dalam menganalisis secara lebih akurat tentang kondisi dan tingkat produktivitas tanaman tersebut. Analisis

This is an open access article

Licensed under the Creative Commons Attribution

International License CC-BY-SA 4.0

(cc) BY-SA pertumbuhan tanaman bermanfaat untuk mengetahui bagaimana pertumbuhan suatu tanaman (Duaja et al. 2013). Kendala utama dalam meningkatkan produksi terung di daerah tropis adalah serangan hama dan tungau. Hama utama terung diantaranya adalah penggerek pucuk dan buah terong, wereng daun, kutu putih (whitefly), thrips, aphid, kumbang lembing, penggulung daun, penggerek batang, kumbang melepuh, tungau merah dan penyakit daun (Srinivasan 2009).

Kerusakan buah terung berpengaruh pada kandungan gizinya yang mempengaruhi minat dari konsumen. Buah terung merupakan produksi utama pada terung itu sendiri saat buah terserang hama maka dapat terjadi penurunan produksi bahkan cukup tinggi. Hama utama pada terong yakni serangga penggerek pucuk dan buah terung (Leucinodes orbonalis Guenee). Pada serangan yang tinggi, hama ini akan sangat berpengaruh pada kualitas buah terung sehingga dapat mengakibatkan gagal panen dan kerugian buat petani (Wowor et al. 2017). Kutu kebul juga dapat menyerang terung. Kehadiran kutu kebul (Bemisia tabaci) pada komoditas sayuran dapat berperan sebagai hama yang merusak secara langsung dan sebagai vektor penyakit virus kuning. Jika populasi hama ini tinggi maka akan 
terlihat embun tepung yang berasal dari sekresi serangga. Embun tepung merupakan tempat yang baik untuk berkembangnya jamur jelaga pada daun tanaman sehingga akan mengurangi efisiensi fotosintesis dari tanaman (Hasyim et al. 2016).

Hama kumbang Henosepilachna sparsa juga sebagai salah satu OPT terung. Hal ini dapat menyebabkan kerugian panen hasil. Kumbang pemakan daun $(H$. sparsa) merupakan salah satu hama penting pada terung dan leunca (Maulani 2015). Jenis serangga lain yang dapat berpengaruh negatif terhadap pertumbuhan dan perkembangan tanaman, terutama tanaman pertanian adalah serangga pemakan daun dari ordo Coleoptera, yaitu kumbang koksi (Epilachna admirabilis). Pada daerah tertentu, misalnya di kecamatan Baturiti, kabupaten Tabanan Bali, kumbang koksi merupakan salah satu hama yang cukup mengkhawatirkan petani, karena serangga ini aktif memakan beberapa jenis tanaman sayuran, misalnya pada terung. Preferensi makan kumbang E. admirabilis terhadap tiga jenis daun cabai (Capsicum annum), terung ( $S$. melongena) dan tomat (Lycopersicum esculentum) pada waktu 2 jam dan 24 jam menunjukkan preferensi makan kumbang tertinggi adalah pada daun tanaman terung dan diikuti oleh daun tomat, sedangkan daun cabai sama sekali tidak disukai oleh kumbang (Suyoga et al. 2016).

Ghosh dan Senapati (2009), larva Leucinodes orbonalis sebagai salah satu hama utama yang menginfestasi terung dapat menyebabkan kerusakan berat di semua sentra terung. Pengendalian hama ini termasuk sangat sulit, karena ia memakan di dalam tunas dan buah. Penelitian Kent dan Taylor (2010) spesies baru Acizzia Heslop-Harrison (Hemiptera: Psyllidae) dari famili tanaman Solanaceae di Australia timur dijelaskan bahwa Acizzia solanicola juga merusak terung pada tanaman komersial dan kebun di Australia bagian timur. Kotey et al. (2013) Aphis gossypii (Glover) dan Thrips tabaci (Lindeman) juga memiliki dampak buruk yang serius pada pertumbuhan dan hasil tanaman terung. Infestasi $T$. tabaci dapat menghasilkan daun dengan ukuran kecil dan buah cacat, sementara hasil $A$. gossypii memiliki kemampuan memproduksi embun madu dengan mengakibatkan perubahan warna daun dan penurunan kualitas buah yang dipasarkan.

Hasil pemuliaan terung saat ini telah menghasilkan beberapa jenis terung dengan aneka warna dan bentuk. Pada umumnya masyarakat mengenal terung dengan warna ungu dan berbentuk lonjong. Saat ini telah dikembangkan beberapa jenis warna terung selain warna ungu seperti warna putih, hijau, atau warna gabungan. Berdasarkan bentuk buah terung umumnya masyarakat mengenal terung berbentuk lonjong, saat ini telah ada bentuk bulat dari buah terung. Limbongan (2012), menyatakan karakter morfologi klon harapan tahan hama PBK (penggerek buah kakao) antara lain adalah bentuk buah elips dan oblong, kulit buah tebal dan permukaan halus, konstriksi buah tidak berlekuk, dan apeks buah tumpul. Kendala dalam budidaya terung tidak lepas adanya serangan organisme pengganggu tanaman (OPT) berupa hama. Kerusakan tanaman oleh hama dapat mengakibatkan adanya penurunan produksi akibat saat fase pertumbuhan dan perkembangan tanaman terung tidak dapat tumbuh dan berkembang secara optimum. Serangan hama selain dapat menurunkan hasil panen, juga dapat menurunkan kualitas hasil panen. Oleh karena itu perlu upaya penggunaan jenis terung yang memiliki ketahanan tinggi terhadap serangan hama.

Upaya memperoleh hasil terung dengan hasil tinggi dapat dilakukan dengan penurunan intensitas serangan OPT. pemilihan jenis/ kultivar tanaman yang sesuai sebagai upaya pengendalian OPT dapat dilakukan dengan penggunaan jenis/ kultivar terung yang tahan terhadap serangan OPT tertentu. Hakim et al. (2017) menjelaskan bahwa ketertarikan serangga terhadap warna adalah salah satu cara adaptasi serangga di alam. Adaptasi ini dapat terjadi pada serangga dengan tujuan melindungi dirinya dari gangguan predator. Ada pengaruh media kertas dan lampu warna kuning, hijau, dan merah terhadap kehadiran serangga pada pertanaman jagung. Hakim et al. (2016) menyatakan bahwa ketertarikan serangga terhadap warna disebabkan pemantulan cahaya kesegala arah dan banyak serangga pemakan tumbuhan menanggapi positif pola pantulan cahaya dari tanaman inang, dan tanggapan ini bisa sangat spesifik. Penelitian ini bertujuan untuk mengetahui intensitas serangan hama pada beberapa jenis tanaman terung dan pengaruhnya terhadap hasil.

\section{BAHAN DAN METODE}

Penelitian ini dilaksanakan bulan Maret hingga Oktober 2017 di lahan percobaan Program Studi Agroteknologi Politeknik Banjarnegara. Lahan percobaan berada di kelurahan Kenteng, kecamatan Madukara, kabupaten Banjarnegara dengan ketinggian tempat 323 mdpl (BPS Kab. Banjarnegara, 2017). Pelaksanaan budidaya terung yang dilakukan menurut Sumpena (2013) yang telah dimodifikasi sebagai berikut:

\section{a.Persemaian}

Media semai berupa tanah: pupuk kotoran sapi dengan perbandingan 1:1. Benih disemai pada polibag semai selama 3 minggu hingga bibit memiliki 4-5 daun. b. Pengolahan lahan

Lahan diolah untuk dibuat bedengan dengan panjang 3,5 m dan lebar 2,5 m. Di antara bedengan dibuat parit dengan jarak antar bedengan 0,5 m. Pupuk dasar berupa pupuk kotoran sapi diberikan $0,5 \mathrm{~kg}$ per lubang tanam.

c. Penanaman

Benih yang seragam dan sehat ditanam dengan jarak tanam $60 \times 70 \mathrm{~cm}$. Bedengan di sekitar bibit yang telah ditanam ditutup dengan mulsa jerami.

d.Pemupukan dan Pemeliharaan Tanaman

Pupuk susulan berupa urea diberikan 2 minggu setelah tanam dengan dosis $65 \mathrm{~kg} / \mathrm{ha}$. Pemupukan berikutnya saat tanaman berumur 3 bulan berupa Urea $150 \mathrm{~kg} / \mathrm{ha}$ dan $\mathrm{KCl} 150 \mathrm{~kg} / \mathrm{ha}$. Pemeliharaan yang dilakukan yaitu penyiangan gulma, penyiraman, dan pemberian ajir.

Rancangan yang digunakan dalam penelitian adalah rancangan acak kelompok lengkap (RAKL). Penelitian dengan 4 perlakuan menggunakan 3 ulangan, sehingga terdapat 12 unit percobaan. Perlakuan yang dicobakan 
yaitu 4 jenis terung sebagai berikutterung ungu (Lezata F1), terung putih (Kania F1), terung hijau (Milano F1), dan terung putih beralur hijau (Jeno F1).

Peubah yang diamati adalah intensitas serangan hama dan komponen pertumbuhan dan hasil pada tanaman terung. Pengamatan intensitas serangan hama tanaman terung dilakukan pada 2 mst. Intensitas serangan hama dihitung dengan rumus Natawigena (1993) sebagai berikut:

$I S=\sum\left(\frac{n x v}{N x Z}\right) x 100 \%$

Dengan IS: Intensitas serangan (\%), $n$ : Jumlah bagian tanaman/tanaman yang diamati pada skala kerusakan tertentu, $v$ : Skala kerusakan serangan oleh OPT pada Tabel 1. N: Jumlah tanaman keseluruhan yang diamati, dan $Z$ : Skala kerusakan tertinggi.

Tabel 1. Kriteria kategori intensitas kerusakan

\begin{tabular}{ccc}
\hline Skala & Persentase & Kriteria \\
\hline 0 & 0 & Normal \\
1 & $0<x \leq 25$ & Ringan \\
2 & $25<x \leq 50$ & Sedang \\
3 & $50<x \leq 75$ & Berat \\
4 & $x>75$ & Sangat berat \\
\hline
\end{tabular}

Pengamatan komponen pertumbuhan berupa tinggi tanaman. Komponen hasil yang diamati berupa jumlah buah pada panen pertama.Analisis data menggunakan Uji $F$, apabila berbeda nyata dilanjutkan dengan DMRT (Duncan's Multiple Range Test) pada taraf 5\%.

\section{HASIL DAN PEMBAHASAN}

Hasil pengamatan tinggi tanaman disajikan pada Gambar 1. Pengamatan tinggi tanaman terung dilakukan pada fase vegetatif pertumbuhan tanaman yaitu pada 2 minggu setelah tanam (mst). Hasil analisis menunjukkan bahwa rerata tinggi tanaman terung terung ungu, terung putih, terung hijau, dan terung putih beralur hijau berturut-turut $7,78 \mathrm{~cm}, 7,17 \mathrm{~cm}, 7,50 \mathrm{~cm}$, dan $7,58 \mathrm{~cm}$. Keempat jenis terung menunjukkan tidak berbeda nyata pada hasil analisis tinggi tanaman. Diduga faktor genetika yang berpengaruh terhadap keempat jenis terung tersebut, semua jenis terung memiliki tinggi tanaman yang setara. Prasetyo dan Hidayanto (2016) perbedaan varietas tanaman berpengaruh terhadap tanaman itu sendiri, pada penelitian tanaman kedelai menyatakan bahwa varietas Sinabung merupakan varietas yang relatif paling tahan terhadap serangan perusak daun, sedangkan varietas Tanggamus, Wilis dan Kaba merupakan varietas yang toleran terhadap kerusakan daun akibat hama perusak daun.

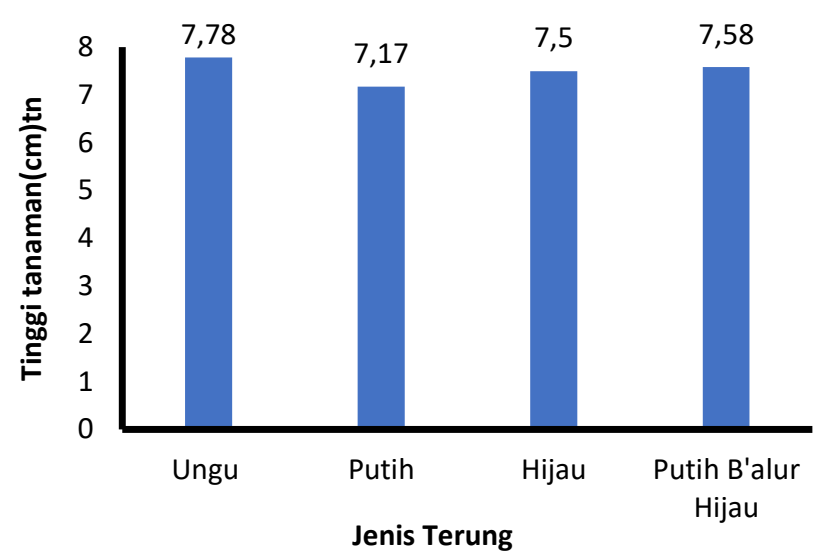

Keterangan: tn = tidak nyata pada DMRT 5\%.

Gambar 1. Tinggi tanaman pada beberapa jenis terung

Santosa dan Sumarmi, (2016) juga menyatakan bahwa pertumbuhan tanaman yang baik dapat dicapai bila faktor lingkungan yang mempengaruhi pertumbuhannya berada dalam keadaan berimbang dan menguntungkan.Faktor- faktor lingkungan tersebut adalah kadar air, udara dan unsur hara dalam tanah.

Hasil pengamatan menunjukkan bahwa hama utama yang menyerang tanaman terung yaitu belalang (Orthroptera: Acrididae), ulat pemakan daun (Lepidoptera: Pyralidae), kumbang lembing Epilachna sp. (Wiedemann) (Coleoptera: Coccinellidae), wereng daun daun Amrasca sp. Distant (Hemiptera: Cicadellidae), dan kutu daun Aphis sp. (Hemiptera: Aphididae). Pengamatan yang dilakukan pada $2 \mathrm{mst}$ didominasi oleh hama perusak daun. Prasetyo dan Hidayanto 2016) menjelaskan bahwa walaupun tanaman mengalami kerusakan akibat serangan OPT, tetapi banyak diantaranya yang tetap bertahan dari serangan dan mampu memberikan hasil yang lebih baik. Selain itu setiap tanaman mempunyai ketahanan yang dipengaruhi oleh lingkungan dimana tanaman akan terbebas dari serangan OPT karena pengaruh faktor lingkungan yang belum mendukung OPT tersebut melakukan perusakan atau infeksi terhadap tanaman tersebut.

Hasil analisis intensitas serangan hama belalang menunjukkan tidak berbeda nyata (Tabel 2.). Intensitas serangan belalang pada terung terung ungu, terung putih, terung hijau, dan terung putih beralur hijau berturut-turut yaitu $3,33,3,76,8,57$, dan $6,67 \%$. Hasil analisis intensitas serangan hama ulat pemakan daun menunjukkan tidak berbeda nyata (Tabel 2). Intensitas serangan ulat daun pada terung $A, B, C$, dan $D$ berturutturut yaitu $7,78,6,25,0,00$, dan $2,78 \%$. Kedua jenis hama tersebut merupakan hama dengan tipe mulut penggigit pengunyah. Tingkat kerusakan oleh hama belalang dan ulat ini sama-sama tidak berbeda nyata.

Hasil analisis intensitas serangan hama kumbang menunjukkan tidak berbeda nyata (Tabel 2.). Intensitas serangan kumbang pada terung $A, B, C$, dan $D$ berturutturut yaitu $5,67,2,00,10,05$, dan $10,81 \%$. Bagian daun yang diserang kumbang ini sebagian besar tinggal tulang daunnya saja. Menurut Suyogaet al. (2016) daun terung dan tomat yang dikonsumsi oleh kumbang $E$. Admirabilis hanya bagian laminanya saja sedangkan bagian tulang dan urat daunnya tidak dikonsumsi. 
Tabel 2. Intensitas serangan hama tanaman terung

\begin{tabular}{|c|c|c|c|c|c|}
\hline Jenis terung & $\begin{array}{l}\text { Belalang } \\
(\%)^{\operatorname{tn}}\end{array}$ & $\begin{array}{l}\text { Ulat pemakan } \\
\text { daun }(\%)^{\text {tn }}\end{array}$ & $\underset{n}{\text { Kumbang}}(\%)^{t}$ & $\underset{n}{\text { Wereng}}(\%)^{t}$ & $\begin{array}{c}\text { Kutu } \\
\text { daun(\%) }\end{array}$ \\
\hline Terung ungu & 3,33 & 7,78 & 5,67 & 1,33 & 0,00 \\
\hline Terung putih & 3,75 & 6,25 & 2,00 & 0,00 & 0,00 \\
\hline Terung hijau & 8,57 & 0,00 & 10,05 & 0,00 & 23,90 \\
\hline $\begin{array}{l}\text { Terung putih beralur } \\
\text { hijau }\end{array}$ & 6,67 & 2,78 & 10,81 & 0,00 & 0,00 \\
\hline
\end{tabular}

Keterangan: $\mathrm{tn}=$ tidak nyata pada DMRT $5 \%$.

Hal ini diduga disebabkan karena bagian daun tersebut lebih lunak sehingga lebih mudah dikonsumsi. Maulani, (2015) menambahkan bahwa intensitas serangan larva kumbang daun pada tanaman terung dan leunca yang paling tinggi pada larva instar IV. Penelitian Ali et al. (2017) menunjukkan kultivar Blue Pearl memiliki sifat paling tahan terhadap serangan $E$. vigintioctopunctata $F$. dengan jumlah telur yang dihasilkan paling sedikit dibandingkan kultivar lainnya.

Hasil analisis intensitas serangan hama wereng menunjukkan tidak berbeda nyata (Tabel 2.). Intensitas serangan wereng pada daun terung ungu, terung putih, terung hijau, dan terung putih beralur hijau berturut-turut yaitu $1,33,0,00,0,00$, dan $0,00 \%$. Hasil analisis intensitas serangan hama kutu daun juga menunjukkan tidak berbeda nyata (Tabel 2.). Intensitas serangan hama kutu daun $A, B, C$, dan $D$ berturut-turut yaitu 0,00 , $0,00,23,90$, dan $0,00 \%$. Kedua jenis hama pengisap daun ini sama-sama menunjukkan tidak berbeda nyata pada intensitas serangannya terhadap tanaman terung. Penelitian Rahman et al. (2011) bahwa infestasi kutu daun Aphis gossypii Glover dan hasil pada dua belas varietas terung selama tiga musim tanam berturut-turut (2005-2006, 2006-2007 dan 2007-2008) menunjukkan hasil terung secara bertahap menurun dan hasil terendah dicatat untuk penanaman periode ketiga yaitu $1,06-1,88 \mathrm{~kg} /$ tanaman.

Hasil analisis jumlah buah terung menunjukkan tidak berbeda nyata (Gambar 2.). Jumlah buah terung ungu, terung putih, terung hijau, dan terung putih beralur hijau berturut-turut $3,08 \mathrm{~g}, 1,94 \mathrm{~g}, 1,58 \mathrm{~g}$, dan $4,72 \mathrm{~g}$. Pengamatan jumlah buah pada panen pertama berupa buah utuh yang sehat. Intensitas serangan hama yang tidak berbeda nyata pada semua jenis terung seiring dengan hasil analisis jumlah buah yang juga menunjukkan tidak berbeda nyata pada semua perlakuan. Muldiana dan Rosdiana (2017), pada proses produksi tanaman, jumlah buah sangat berkaitan dengan jumlah bunga yang terbentuk oleh tanaman itu sendiri, hal ini juga di dukung oleh keadaan lingkungan sekitar. Penelitian Safei et al. (2014) perbedaan hasil produksi dapat disebabkan karena kandungan unsur hara dalam tanah tergolong sangat rendah sampai sedang, sehingga tanaman tidak dapat tumbuh dengan

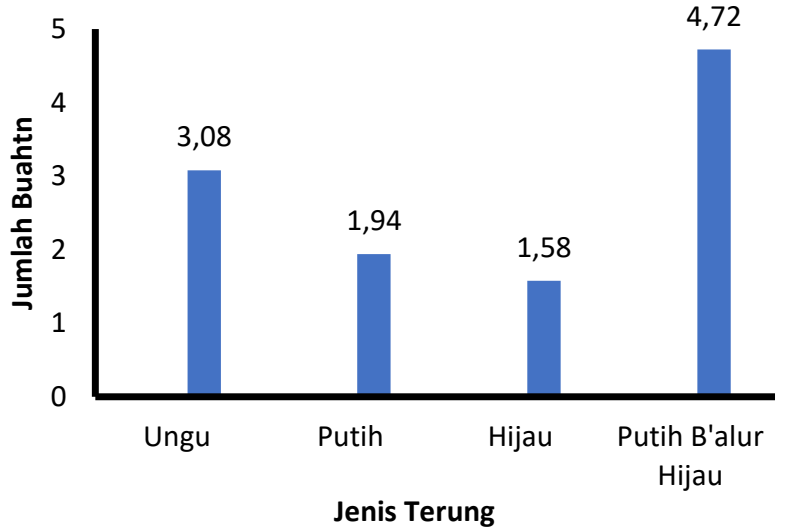

Keterangan: tn = tidak nyata pada DMRT 5\%.

Gambar 2. Jumlah buah pada beberapa jenis terung

baik. Dengan pemberian pupuk organik dapat memperbaiki sifat fisik, kimia dan biologis tanah, sehingga dapat meningkatkan ketersediaan dan serapan unsur hara oleh tanaman terung yang selanjutnya tanaman dapat tumbuh dan berkembang dengan baik.

\section{KESIMPULAN}

Intensitas serangan hama belalang (Orthroptera: Acrididae), ulat pemakan daun (Lepidoptera: Pyralidae), kumbang lembing Epilachna sp. (Wiedemann) (Coleoptera: Coccinellidae), wereng daun daun Amrasca sp. Distant (Hemiptera: Cicadellidae), dan kutu daun Aphis sp. (Hemiptera: Aphididae) pada jenis terung ungu, terung putih, terung hijau, dan terung putih beralur hijau menunjukkan tidak berbeda nyata. Intensitas serangan hama yang tidak berbeda nyata pada semua jenis terung seiring dengan hasil analisis tinggi tanaman dan jumlah buah yang juga menunjukkan tidak berbeda nyata pada semua perlakuan.

\section{DAFTAR PUSTAKA}

Aer BN, Wullur AC, Citraningtyas G. 2013. Uji efek ekstrak etanol kulit terung unggu (Solanum melongena L.) terhadap kadar gula darah pada tikus putih jantan galur wistar (Rattus norvegicus). Pharmacon J Ilmiah Farmasi. 2 (4) : 135 - 141. 
Ali A, Javed K, Javed H, Kassi AK, Aslam MR, Hussain K, Ahmad T. 2017. Screening of different brinjal (Solanum melongena L.) cultivars against hadda beetle (Epilachna vigintioctopunctata F.) in Pothwar region. Journal of Entomology and Zoology Studies 2017; 5(1): 786-791

BPS Kab. Banjarnegara. 2017. Kecamatan madukara dalam Angka 2017. BPS Kab. Banjarnegara.

Duaja MD, Arzita, Simanjuntak P. 2013. Analisis tumbuh dua varietas terung (Solanum melongena L.) pada perbedaan jenis pupuk organik cair. Bioplantae. 2 (1) : 33-39.

Ghosh SK, Senapati SK. 2009. Seasonal fluctuation in the population of Leucinodes orbonalis Guen. in the sub-himalayan region of West Bengal, India and its control on eggplant (Solanum melongena L.). Precision Agriculture. 10 (ㅁ) : 443-449.

Hakim L, Surya E, Muis A. 2016. Pengendalian alternatif hama serangga sayuran dengan menggunakan perangkap kertas. J Agro. 3 (2) : 21-33.

Hakim L, Surya E, Muis A. 2017. Pengendalian alternatif hama serangga sayuran dengan menggunakan warna sebagai perangkap mekanis. Serambi Saintia. 5 (1) : $33-44$.

Hastuti LDS. 2007. Terung. Tinjauan Langsung Kebeberapa Pasar Di Kota Bogor. Program Studi Biologi. Fakultas Matematika dan IImu Pengetahuan Alam Universitas Sumatera Utara. USU Repository; $\begin{array}{llll}\text { [Diakses } & 8 & \text { September }\end{array}$ http://library.usu.ac.id/download/fmipa/07002689.pdf

Hasyim A, Setiawati W, Liferdi L. 2016. "Kutu Kebul Bemisia tabaci Gennadius (Hemiptera: Aleyrodidae) Penyebar Penyakit Virus Mosaik Kuning pada Tanaman Terung." IPTEK Hortikultura. No. 12, September 2016. (Hal. 50 - 54).

Kadir DAA, Kadirman, Jamaluddin. 2015. Penerapan sistem osmotic dehydration untuk mengurangi kadar lemak keripik buah pada penggorengan tekanan hampa udara. J Pendidikan TeknolPertan1 : 22-29 22

Kent D, Taylor G. 2010. Two new species of Acizzia Crawford (Hemiptera: Psyllidae) from the Solanaceae with a potential new economic pest of eggplant, Solanum melongena. Australian Journal of Entomology. 49(1): 73-81.

Kotey DA, Osekre EA, Badger NG, Ahiatsi EN. 2013. Evaluation of eggplant, Solanum spp. germplasm against field insect pests' infestation at Bunso in the Eastern Region of Ghana. Journal of Biology, Agriculture and Healthcare. 3(18):28-36.

Limbongan J. 2012. Karakteristik morfologis dan anatomis Klon harapan tahan penggerek buah Kakao sebagai sumber bahan tanam. J Litbang Pertan. $31(1): 14-20$.

Maulani NW. 2015. Identifikasi dan evaluasi musuh alami kumbang pemakan daun (Henosepilachna sparsa) pada tanaman terung (Solanum melongena
L.) dan leunca (Solanum nigrum). J Agrorektan. 2 (1) : 10-20.

Muldiana S, Rosdiana. 2017. Respon tanaman terong (Solanum malongena L.) terhadap interval pemberian pupuk organic cair dengan interval waktu yang berbeda. Prosiding Seminar Nasional 2017 Fakultas Pertanian UMJ. "Pertanian dan Tanaman Herbal Berkelanjutan di Indonesia." 8 November 2017. Hal : 155 - 162.

Natawigena H. 1993. Dasar-dasar Perlindungan Tanaman. Bandung (ID): Trigenda Karya.

Panah Merah. 2018. Product. PT East West Seed Indonesia.Purwakarta.http://www.panahmerah.id/pro duct. Diakses 2 September 2017.

Prasetyo WB. dan Hidayanto, M. 2016. Kajian ketahanan beberapa VUB kedelai terhadap serangan hama pemakan daun di kabupaten Kutai Timur. Prosiding Seminar Nasional Inovasi Teknologi Pertanian. Banjarbaru, 20 Juli 2016.

Rahman MM, Sarker PK, Das BC. 2011. Effect of planting date on the incidence of eggplant aphid, Aphis gossypii Glover and yield of eggplant. Bangladesh J. Zool. 39(2): 187-194.

Safei M, Rahmi A, Jannah N. 2014. Pengaruh jenis dan dosis pupuk organik terhadap pertumbuhan dan hasil tanaman terung (Solanum melongena L.) varietas mustang F-1. J Agrifor. 12 (1) : 59 - 66.

Sahid OT, Murti RH, Trisnowati S. 2014. Hasil dan Mutu Enam Galur Terung (Solanum melongena L.). Vegetalika. 3 (2) : $45-58$.

Santosa SJ, Sumarmi. 2016. Pengaruh konsentrasi ekstrak teh dan macam media terhadap pertumbuhan dan hasil tanaman terong di polybag. Joglo. 28 (2) : 71-77.

Setiawati W, Murtiningsih R, Sopha GA, Handayani T. 2007. Petunjuk Teknis Budidaya Tanaman Sayuran. Balai Penelitian Tanaman Sayuran. Bandung. Hal.118-126.

Srinivasan R. 2009. Serangga Hama dan Tungau pada Tanaman Terung. Buku panduan untuk idendifikasi dan pengelolaan. Terjemahan oleh Ahsol Hasyim, Wiwin Setiawati, Liferdi Lukman, dan Abdi Hudayya. Balai Penelitian Tanaman Sayuran. Bandung.

Sumpena U. 2013. Budidaya Terung. Poster. Bandung (ID): Balai Penelitian Tanaman Sayuran.

Suyoga KB, Watiniasih, N.L., dan Suartini, N.M. 2016. Preferensi makan kumbang koksi (Epilachna admirabilis) pada beberapa tanaman sayuran famili Solanaceae. J Simbiosis. 4 (1): 19-21.

Wowor EK, Kaligis JB, Caroulus CS. 2017. Persentase serangan Leucinodes orbonalis Gueene (Lepidoptera; Crambidae) pada buah terong di Kelurahan Wailan dan kakaskasen dua Kecamatan Tomohon Utara. Cocos. 1 (3) : 1-11. 